\title{
Research Status and Future Development of Biomass Liquid Fuels
}



Due to the combined pressures of energy shortage and environmental degradation, bio-liquid fuels have been widely studied as a green, environmentally friendly, renewable petroleum alternative. This article summarizes the various technologies of three generations of biomass feedstocks (especially the second-generation, biomass lignin, and the third-generation, algae raw materials) used to convert liquid fuels (bioethanol, biodiesel, and bio-jet fuel) and analyzes their advantages and disadvantages. In addition, this article details the latest research progress in biomass liquid fuel production, summarizes the list of raw materials, products and conversion processes, and provides personal opinions on its future development. The aim is to provide a theoretical basis and reference for the optimization of existing technology and future research and development of biomass liquid fuels.
\end{abstract}

Keywords: Biomass liquid fuel; Bioethanol; Biodiesel; Biomass jet fuel

Contact information: a: Key Laboratory of Energy Saving Technology of Food and Pharmaceutical Storage and Processing and Transportation Equipment in Good Quality (China National Light Industry), The Technical Institute of Physics and Chemistry of the Chinese Academy of Sciences, Beijing 100190, China; b: College of Forestry, Jiangxi Agricultural University, National Forestry and Grassland Bureau Woody Spice (East China) Engineering Technology Research Center, Nanchang 330045, China; Tianjin 300222, China; *Corresponding author: zzt@ mail.ipc.ac.cn

\section{INTRODUCTION}

The development of modern industry provides prosperity but leads to the wasting of biomass resources. In recent years, the transformation and utilization of these green, inexpensive, and readily available waste biomass resources have become urgent and important issues in the fields of environmental protection and chemical industry. Coupled with the dual pressures of energy shortage and environmental deterioration, countries around the world have begun to compete to develop safe, environmentally friendly, and renewable biomass energy. The development and application of biomass liquid fuels have attracted unique attention and extensive research in many countries. Biomass liquid fuels generally refer to liquid fuels, such as bioethanol, biodiesel, and bio-jet fuel, which are converted from biomass using various technologies. Biomass liquid fuel technology has developed rapidly in the past three decades. Biomass liquid fuel has become the most promising class of alternative fuel, and biodiesel and bioethanol have achieved particularly large-scale development (Dabros et al. 2018; Efeovbokhan et al. 2019).

As shown in Table 1, current biomass liquid fuels are mainly developed from three generations of raw materials. The first generation of biofuels mainly uses food crops and animal fats as raw materials. Bioethanol and biodiesel are produced via fermentation and transesterification reactions. The relevant production technology has a long history of use, but due to food scarcity concerns, it has become a less favorable option. The secondgeneration biofuels mainly use non-grain crops, such as lignocellulosic biomass as raw 
materials, which include straw, hay, bagasse, rice husks, wood chips, and others. The use of second-generation biofuels causes many technical problems, and there are major problems with conversion rates and production costs.

Table 1. Generations of Biomass Fuel

\begin{tabular}{|c|c|c|c|}
\hline Biomass Fuel & Feedstock & Method & Product \\
\hline $\begin{array}{c}\text { First- } \\
\text { generation }\end{array}$ & $\begin{array}{c}\text { Food crops and } \\
\text { animal fats }\end{array}$ & Biochemical & Bioethanol and biodiesel \\
\hline $\begin{array}{c}\text { Second- } \\
\text { generation }\end{array}$ & $\begin{array}{c}\text { Lignocellulosic } \\
\text { biomass }\end{array}$ & $\begin{array}{c}\text { Biochemical and } \\
\text { thermochemical }\end{array}$ & $\begin{array}{c}\text { Bioethanol, biodiesel, and } \\
\text { bio-jet fuel }\end{array}$ \\
\hline $\begin{array}{c}\text { Third- } \\
\text { generation }\end{array}$ & Algal biomass & $\begin{array}{c}\text { Biochemical and } \\
\text { thermochemical }\end{array}$ & $\begin{array}{c}\text { Bioethanol, biodiesel, and } \\
\text { bio-jet fuel }\end{array}$ \\
\hline
\end{tabular}

In the past few decades, in-depth research on second-generation biomass materials had focused on the enhancement of biomass pretreatment, the production of cellulolytic enzymes, and the improvement of strains and processes. Such efforts have eliminated some major technical bottlenecks. However, there is a need to further reduce processing costs to obtain sufficient market competitiveness. In particular, it is important to reduce the energy requirements in the pretreatment process, increasing sugar concentration, improving enzyme activity and strain recycling, and increasing the utilization of by-products (Guerrero et al. 2018). The third-generation biofuels mainly use algae as a raw material to extract oil and fat. Algae has wide distribution, high oil content, strong environmental adaptability, a short growth cycle, and high yield. Its growth does not occupy the two major resources of land and fresh water, but the production process is still in the laboratory stage. To achieve commercial large-scale production, many technical problems need to be solved (Kabir et al. 2019; Vintila et al. 2019)

\section{RESEARCH STATUS OF BIOETHANOL TECHNOLOGY}

Bioethanol refers to the conversion of various biomass into fuel alcohol via the fermentation of microorganisms. In contrast with first-generation biomass ethanol, which uses sugar- and starch-based crops as raw materials, second-generation biomass ethanol is mainly produced from lignocellulosic biomass, which can be divided into agricultural, forestry residues, energy crops (such as bagasse, rice husk, and straw). Second-generation bioethanol is produced through pretreatment, hydrolysis, and fermentation (Ayodele et al. 2019). Table 2 shows current research of bioethanol produced from second-generation biomass using different pretreatment methods, microorganisms, and fermentation conditions. The purpose of biomass pretreatment is to reduce the crystallinity of cellulose, increase the specific surface area of the substrate, break the barrier effect of hemicellulose and lignin, and facilitate the contact and reaction of cellulose with hydrolytic enzymes. The pretreatment of lignocellulose can adopt physical (such as mechanical communication and irradiation), chemistry (such as acid, alkali, ionic liquid, organic solvent, and ozone pretreatment), physical chemistry (such as steam explosion, ammonia fiber, and $\mathrm{CO}_{2}$ explosion) and biological (such as microorganism) pretreatment methods. Among them, steam explosion is a particularly promising pretreatment method for large-scale production of bioethanol. Guerrero et al. (2018) used steam explosion to pretreat banana waste and found that it has a high hemicellulose recovery rate and cellulose enzymatic hydrolysis 
efficiency, low energy consumption, and a lack of recycling issues. The hydrolysis process is the degradation of the hemicellulose and cellulose polymeric sugars in the raw materials into fermentable monosaccharides. The fermentation reaction uses the hydrolyzed monosaccharide as a raw material, and it is transformed into bioethanol by the metabolism of yeast or bacteria.

Table 2. Production of Bioethanol Using Second-generation Raw Materials

\begin{tabular}{|c|c|c|c|c|c|c|c|}
\hline Feedstock & Pretreatment & Microorganisms & $\begin{array}{c}\text { Fermentation } \\
\text { Conditions }\end{array}$ & $\begin{array}{c}\text { Conversion } \\
\text { Process }\end{array}$ & $\begin{array}{l}\text { Yield } \\
(\%)\end{array}$ & $\begin{array}{l}\text { Yield } \\
\text { (g/L) }\end{array}$ & Reference \\
\hline $\begin{array}{l}\text { Sugarcane } \\
\text { bagasse }\end{array}$ & $\begin{array}{c}\text { Alkaline } \\
\text { pretreatment }\end{array}$ & $\begin{array}{c}\text { Cellulase and } \\
\text { Saccharomyces } \\
\text { cerevisiae }\end{array}$ & $4.5 \mathrm{pH}, 34{ }^{\circ} \mathrm{C}$ & $\begin{array}{l}\text { 34\% WIS/ } \\
\text { /SHF }\end{array}$ & 77.2 & 82.8 & $\begin{array}{l}\text { (Ye et al. } \\
2018)\end{array}$ \\
\hline $\begin{array}{c}\text { Sugarcane } \\
\text { leaf }\end{array}$ & $\begin{array}{l}\text { Ammonia fibre } \\
\text { explosion } \\
\text { pretreatment }\end{array}$ & $\begin{array}{c}\text { Saccharomyces } \\
\text { Cerevisiae (424A } \\
\text { LNH-ST) }\end{array}$ & $4.8 \mathrm{pH}, 30^{\circ} \mathrm{C}$ & $\begin{array}{c}17.7 \% \\
\text { WIS/PSSCF }\end{array}$ & 91.6 & 35.8 & $\begin{array}{l}\text { (Krishnan et } \\
\text { al. 2010) }\end{array}$ \\
\hline $\begin{array}{l}\text { Banana } \\
\text { waste }\end{array}$ & $\begin{array}{l}\text { Acid-catalyzed } \\
\text { steam } \\
\text { explosion }\end{array}$ & $\begin{array}{c}\text { Saccharomyces } \\
\text { cerevisiae and ethanol } \\
\text { red }\end{array}$ & $4.8 \mathrm{pH}, 38^{\circ} \mathrm{C}$ & $\begin{array}{l}17.6 \% \text { WIS } \\
\text { /PSHF }\end{array}$ & 87.0 & 42.1 & $\begin{array}{l}\text { (Guerrero et } \\
\text { al. 2018) }\end{array}$ \\
\hline $\begin{array}{l}\text { Hardwood } \\
\text { waste }\end{array}$ & $\begin{array}{l}\text { Hydroperoxide } \\
\text { and acetic acid } \\
\text { pretreatment }\end{array}$ & $\begin{array}{c}\text { Saccharomyces } \\
\text { cerevisiae and Pichia } \\
\text { stipites }\end{array}$ & $5.0 \mathrm{pH}, 37^{\circ} \mathrm{C}$ & $\begin{array}{c}5.0 \% \\
\text { WIS/SHF }\end{array}$ & 80.7 & 14.8 & $\begin{array}{l}\text { (Song et al. } \\
\text { 2019) }\end{array}$ \\
\hline $\begin{array}{l}\text { Vetiver } \\
\text { grass }\end{array}$ & $\begin{array}{l}\text { Alkaline-acid } \\
\text { pretreatment }\end{array}$ & $\begin{array}{c}\text { Saccharomyces } \\
\text { cerevisiae TISTR } 5339\end{array}$ & $5.0 \mathrm{pH}, 30^{\circ} \mathrm{C}$ & $\begin{array}{l}5.0 \% \text { WIS/ } \\
\text { SHF }\end{array}$ & 73.8 & 21.1 & $\begin{array}{l}\text { (Subsamran } \\
\text { et al. 2019) }\end{array}$ \\
\hline $\begin{array}{l}\text { Wheat } \\
\text { straw }\end{array}$ & $\begin{array}{c}\mathrm{H}_{2} \mathrm{SO}_{4} \\
\text { catalyzed } \\
\text { steam } \\
\text { explosion } \\
\text { pretreatment }\end{array}$ & $\begin{array}{l}\text { Saccharomyces } \\
\text { cerevisiae }\end{array}$ & $4.8 \mathrm{pH}, 34{ }^{\circ} \mathrm{C}$ & $\begin{array}{l}9 \% \text { WIS/ } \\
\text { SSHF }\end{array}$ & 70.8 & 39.2 & $\begin{array}{l}\text { (Olofsson et } \\
\text { al. 2008) }\end{array}$ \\
\hline Brave straw & $\begin{array}{l}\mathrm{SO}_{2} \text { catalyzed } \\
\text { steam } \\
\text { explosion } \\
\text { pretreatment } \\
\end{array}$ & $\begin{array}{c}\text { Saccharomyces } \\
\text { cerevisiae (TMB3006, } \\
\text { TMB3400), Pichia } \\
\text { stipitis CBS } 6054 \\
\end{array}$ & $5.5 \mathrm{pH}, 30^{\circ} \mathrm{C}$ & $\begin{array}{l}8 \% \text { WIS/ } \\
\text { SSHF }\end{array}$ & 87.0 & 40.2 & $\begin{array}{c}\text { (Carrasco et } \\
\text { al. 2010) }\end{array}$ \\
\hline Corn stover & $\begin{array}{l}\text { Ammonia fibre } \\
\text { explosion } \\
\text { pretreatment }\end{array}$ & $\begin{array}{c}\text { Saccharomyces } \\
\text { cerevisiae }\end{array}$ & $\begin{array}{l}5.5 \sim 6.0 \mathrm{pH}, \\
37^{\circ} \mathrm{C}\end{array}$ & $\begin{array}{l}18 \% \text { WIS/ } \\
\text { SSHF }\end{array}$ & 92.7 & 47.2 & $\begin{array}{l}\text { (Lau and } \\
\text { Dale 2010) }\end{array}$ \\
\hline
\end{tabular}

The common processes after pretreatment mainly include separate consolidated bioprocessing, separate hydrolysis and fermentation, and simultaneous hydrolysis and fermentation (SHF). Among them, the SHF method after steam pretreatment of the secondgeneration biomass feedstock is widely regarded as one of the most promising methods for producing bioethanol. To maximize ethanol production in bioethanol production, it is necessary to consider the use of xylose in the hemicellulose portion of lignocellulose while minimizing the inhibitory effect on the fermentation process. As Saccharomyces cerevisiae cannot effectively ferment xylose, Subsamran et al. (2019) studied the engineered strain of Saccharomyces cerevisiae and found that it can effectively co-ferment glucose and xylose, thereby greatly improving the ethanol yield. The final yield of bioethanol mainly depends on the pretreatment technology, hydrolysis process, and fermentation efficiency. 
Table 3. Summary of Pretreatment Processes of Bioethanol from Macroalgae

\begin{tabular}{|c|c|c|c|c|}
\hline Macroalgae & $\begin{array}{l}\text { Pretreatment } \\
\text { Methods }\end{array}$ & Preprocessing Steps & $\begin{array}{l}\text { Fermentable } \\
\text { Reducing } \\
\text { Sugar }\end{array}$ & Reference \\
\hline \multicolumn{5}{|c|}{ Chlorophyta } \\
\hline $\begin{array}{c}\text { Green } \\
\text { seaweed (Ulva } \\
\text { rigida) }\end{array}$ & $\begin{array}{c}\text { Thermal acid } \\
\text { hydrolysis }\end{array}$ & $\begin{array}{l}\text { 1. Green seaweed was } \\
\text { dried in an oven at } 60{ }^{\circ} \mathrm{C} \\
\text { for } 24 \mathrm{~h} \text { and ground into } \\
\text { powder through a blender. } \\
\text { 2. Algal powder of } 10 \% \\
\text { (w/v) was treated with } 4 \% \\
\text { (v/v) } \mathrm{H}_{2} \mathrm{SO}_{4} \text { for } 60 \mathrm{~min} \text {. }\end{array}$ & $34 \mathrm{~g} / \mathrm{L}$ & $\begin{array}{c}\text { (El Harchi et al. } \\
\text { 2018) }\end{array}$ \\
\hline $\begin{array}{c}\text { Green } \\
\text { macroalgae } \\
\text { (Ulva lactuca) }\end{array}$ & $\begin{array}{l}\text { 1. Liquid hot } \\
\text { water } \\
\text { pretreatment; } \\
\text { 2. Enzymatic } \\
\text { hydrolysis }\end{array}$ & $\begin{array}{l}\text { 1. } 15 \mathrm{~g} \text { algal biomass was } \\
\text { mixed with } 150 \mathrm{~mL} \text { distilled } \\
\text { water for } 2 \mathrm{~h} \text { at } 170{ }^{\circ} \mathrm{C} \text {. } \\
\text { 2. The enzymatic hydrolysis } \\
\text { experiments were } \\
\text { performed at } 50^{\circ} \mathrm{C} \text { and } \\
\text { with an enzyme activity } \\
\text { equal to } 10 \mathrm{U} / \mathrm{g} \text { of biomass. }\end{array}$ & $\begin{array}{c}62.9 / 100 \mathrm{~g} \\
\mathrm{DM}^{*}\end{array}$ & $\begin{array}{c}\text { (Jmel et al. } \\
2018)\end{array}$ \\
\hline $\begin{array}{c}\text { Chaetomorpha } \\
\text { sp. and Ulva } \\
\text { sp. }\end{array}$ & $\begin{array}{l}\text { 1. Alkali } \\
\text { pretreatment; } \\
\text { 2. Enzymatic } \\
\text { hydrolysis }\end{array}$ & $\begin{array}{l}\text { 1. Chaetomorpha sp. and } \\
\text { Ulva sp were autoclaved for } \\
20 \text { min at } 120^{\circ} \mathrm{C}(1.5 \text { bars }) \\
\text { without a catalyst in the } \\
\text { presence of } 3 \% \mathrm{NaOH} \text {. } \\
2 . \text { An enzyme activity of } 25 \\
\mathrm{U} / \mathrm{mg} \text { of proteins }(10.96 \mathrm{U} \\
\left.\mathrm{CMCase}{ }^{\star *}\right) \text { hydrolyzed } \\
2.5 \% \text { biomass at } 120 \mathrm{rpm} \\
\text { and } 45^{\circ} \mathrm{C} \text { for } 40 \mathrm{~h} \text {. }\end{array}$ & $210 \mathrm{mg} / \mathrm{g}$ & $\begin{array}{c}\text { (Yahmed et al. } \\
\text { 2018) }\end{array}$ \\
\hline \multicolumn{5}{|c|}{ Phaeophyta } \\
\hline $\begin{array}{c}\text { Brown } \\
\text { (Sargassum } \\
\text { latifolium) }\end{array}$ & $\begin{array}{l}\text { 1. Neutral } \\
\text { thermal } \\
\text { hydrolysis; } \\
\text { 2. Fungal } \\
\text { hydrolysis }\end{array}$ & $\begin{array}{l}1.10 \mathrm{~g} \text { wet macroalgae } \\
\text { biomass was previously } \\
\text { subjected to thermal } \\
\text { hydrolysis, then was kept in } \\
\text { an autoclave at } 120^{\circ} \mathrm{C} \text { for } \\
15 \text { min }(1.5 \text { bar, } 5.5 \mathrm{pH}) \text {. } \\
\text { 2. Trichoderma asperellum } \\
\text { RM was kept under static } \\
\text { conditions for } 21 \mathrm{~d} \text { at } 30^{\circ} \mathrm{C} \text {. }\end{array}$ & $510 \mathrm{mg} / \mathrm{g}$ & $\begin{array}{c}\text { (Soliman et al. } \\
\text { 2018) }\end{array}$ \\
\hline $\begin{array}{c}\text { Brown } \\
\text { seaweed } \\
\text { (Sargassum } \\
\text { crassifolium) }\end{array}$ & $\begin{array}{l}\text { 1. Physical } \\
\text { and chemical } \\
\text { pretreatment; } \\
\text { 2. Enzymatic } \\
\text { hydrolysis }\end{array}$ & $\begin{array}{l}\text { 1. Sulphuric acid }(0.2 \mathrm{M}) \\
\text { was kept at } 121^{\circ} \mathrm{C} \text { for } 15 \\
\text { min with } 15 \mathrm{Ps} \text {. } \\
\text { 2. Cellulase }(0.5 \mathrm{~g} / \mathrm{mL}) \\
\text { was kept at } 30^{\circ} \mathrm{C} \text { for } 10 \\
\text { min }(1500 \mathrm{rpm}, 5.5 \mathrm{pH}) \text {. }\end{array}$ & $68.3 \mathrm{~g} / \mathrm{L}$ & $\begin{array}{l}\text { (Widyaningrum } \\
\text { et al. 2016) }\end{array}$ \\
\hline \multicolumn{5}{|c|}{ Rhodophyta } \\
\hline $\begin{array}{c}\text { Brown } \\
\text { seaweed } \\
\text { (Sargassum } \\
\text { sp.) }\end{array}$ & $\begin{array}{c}1 . \\
\text { Mechanical } \\
\text { pretreatment; } \\
2 . \text { Acid } \\
\text { hydrolysis; } \\
\text { 3. Enzyme } \\
\text { hydrolysis }\end{array}$ & $\begin{array}{l}\text { 1. The powdered seaweed } \\
\text { was desalinated, filtered or } \\
\text { centrifuged, and spray dried } \\
\text { on steam heated drums. } \\
\text { 2. The } 4 \% \text { concentration of } \\
\mathrm{H}_{2} \mathrm{SO}_{4} \text { was held in an } \\
\text { autoclave at } 121^{\circ} \mathrm{C} \text { for } \\
30 \text { min and then placed in a }\end{array}$ & $110.0 \mathrm{mg} / \mathrm{g}$ & $\begin{array}{c}\text { (Saravanan et } \\
\text { al. 2018) }\end{array}$ \\
\hline
\end{tabular}




\begin{tabular}{|c|c|c|c|c|}
\hline & & $\begin{array}{c}\text { centrifuge at } 150 \mathrm{rpm} \text { for } 1 \mathrm{~h} \\
\text { at } 30^{\circ} \mathrm{C} \text {. } \\
\text { 3. Cellulase }(53 \mathrm{FPU} / \mathrm{g}) \text { and } \\
\text { pectinase }(20 \mathrm{U}) \text { were held } \\
\text { at } 50^{\circ} \mathrm{C} \text { for } 4 \mathrm{~h}(150 \mathrm{rpm} \text {, } \\
5.0 \mathrm{pH}) \text {. Then they were } \\
\text { centrifuged at } 8000 \mathrm{rpm} \text { for } \\
10 \mathrm{~min} \text {. }\end{array}$ & & \\
\hline Gracilaria spp. & $\begin{array}{l}\text { 1. Acid } \\
\text { hydrolysis; } \\
\text { 2. Enzymatic } \\
\text { hydrolysis }\end{array}$ & $\begin{array}{l}\text { 1. Gracilaria spp. was } \\
\text { mixed with } 0.1 \mathrm{~N} \\
\text { hydrochloric acid and } 2 \% \\
\text { seaweed slurry, then kept } \\
\text { for } 15 \text { mins at } 121^{\circ} \mathrm{C} \text {. } \\
\text { 2. Acid hydrolysis products } \\
\text { were mixed with } \\
\text { recombinant enzyme (aga } \\
50 \mathrm{D} 0.5 \mathrm{U} / \mathrm{mg}+\mathrm{NABH} 0.5 \\
\mathrm{U} / \mathrm{mg} \text { ) in a laboratory } \\
\text { incubator at } 200 \mathrm{rpm} \text { for } 48 \\
\mathrm{~h} \text {. } \\
\text { 3. Then, after the sample } \\
\text { was boiled for } 5 \text { min, it was } \\
\text { centrifuged at } 30,000 \mathrm{~g} \text { for } \\
20 \text { min. }\end{array}$ & $47.4 \%$ & $\begin{array}{c}\text { (Kim et al. } \\
2018)\end{array}$ \\
\hline $\begin{array}{l}\text { Gelidium } \\
\text { amansii }\end{array}$ & $\begin{array}{l}\text { Dicationic } \\
\text { acidic ionic } \\
\text { liquids } \\
\text { (DAlLs) }\end{array}$ & $\begin{array}{l}\text { 1. DAlLs were synthesized } \\
\text { from oligo (ethylene glycol), } \\
\text { methanesulfonyl chloride, } \\
\mathrm{N} \text {-methylimidazole and } \\
\mathrm{H}_{2} \mathrm{SO}_{4} \text {, then vacuum dried } \\
\text { for } 1 \mathrm{~h} \text { at } 60^{\circ} \mathrm{C} \text {. } \\
2.5 \mathrm{wt} \% \text { Gelidium amansii } \\
\text { was mixed with DAILs }(0.5 \\
\text { mmol) and kept for } 3 \text { min at } \\
120^{\circ} \mathrm{C} \text {. }\end{array}$ & $67.5 w t \%$ & $\begin{array}{c}\text { (Malihan et al. } \\
\text { 2017) }\end{array}$ \\
\hline \multicolumn{5}{|c|}{ Macroalgal Residual Biomass } \\
\hline $\begin{array}{c}\text { Brown } \\
\text { seaweed } \\
\text { spent biomass }\end{array}$ & $\begin{array}{l}\text { Mild acid } \\
\text { treatment }\end{array}$ & $\begin{array}{l}1.10 \%(\mathrm{w} / \mathrm{v}) \text { substrate } \\
\text { concentration and } 50 \mathrm{~mL} \text { of } \\
1 \% \mathrm{H}_{2} \mathrm{SO}_{4} \text { were autoclaved } \\
\text { at } 121^{\circ} \mathrm{C} \text { for } 20 \mathrm{~min} \text {. }\end{array}$ & $13.1 \mathrm{mg} / \mathrm{g}$ & $\begin{array}{c}\text { (Sudhakar et } \\
\text { al. 2016) }\end{array}$ \\
\hline
\end{tabular}

The second-generation bioethanol mainly uses lignocellulosic materials as raw materials. The main limitation is that it contains a large amount of lignin and requires a large amount of arable land or forest land for cultivation. The use of algae raw materials, such as microalgae and macroalgae, to produce ethanol is called third-generation bioethanol. Macroalgae is a particularly rich source of carbohydrates in bioethanol production. Due to the high carbon and low lignin content of algae raw materials, the thirdgeneration bioethanol, which uses algae as raw materials, has higher octane number, higher heat of vaporization, and less greenhouse gas emissions (Yahmed et al. 2018). The production of bioethanol from macroalgae consists of mechanical pre-processing, pretreatment, and microbial fermentation. The most important step is pretreatment, which destroys or changes the cell wall through physical, chemical, and biological means and releases biomolecules, such as cellulose and sugar polymers, thereby improving the 
saccharification and bioethanol production efficiency. The efficiency of the pretreatment process is mainly determined by cellulose crystallinity, hemicellulose fraction, and the accessible surface area for enzymatic hydrolysis. In addition, an effective pretreatment method should retain some portion (such as pentose) of hemicellulose and reduce the formation of fermentation inhibitors (Dave et al. 2019). Table 3 summarizes recent examples of the production of bioethanol using macroalgae as a raw material and using different pretreatment methods, such as mechanical, chemical, and enzymatic pretreatment. In most cases, enzymatic hydrolysis after dilute acid treatment or alkali treatment is an economically viable pretreatment method for the production of bioethanol. Saravanan et al. (2018) found that, prior to saccharification, mechanical pretreatment of the macroalgal biomass, such as washing, drying, and grinding, coupled with acid and enzymatic hydrolysis, could improve saccharification efficiency. Chemical methods using weak base treatment or dilute acid treatment have also been widely used. The disadvantage of alkaline pretreatment is that it requires a large amount of water for desalination, which increases production costs. In acid pretreatment, dilute sulfuric acid can be used for almost every kind of macroalgae. The factors that ultimately affect the pretreatment process include $\mathrm{pH}$, temperature, processing time, substrate concentration, and the reagents used for pretreatment.

\section{RESEARCH STATUS OF BIODIESEL TECHNOLOGY}

\section{Table 4. Advantages and Disadvantages of Various Biodiesel Production Technologies}

\begin{tabular}{|c|c|c|c|}
\hline $\begin{array}{c}\text { Production } \\
\text { Technologies }\end{array}$ & Advantages & Disadvantages & Reference \\
\hline Catalytic distillation & Easily separable products & $\begin{array}{c}\text { Equipment is easily } \\
\text { corroded, and production } \\
\text { consumes large amounts of } \\
\text { energy }\end{array}$ & $\begin{array}{c}\text { (Singh et al. } \\
2019 \mathrm{a} ; \\
\text { Wong et al. } \\
2019)\end{array}$ \\
\hline Dilution & Easy process & $\begin{array}{c}\text { Poor quality of prepared } \\
\text { biodiesel }\end{array}$ & $\begin{array}{c}\text { (Mahlia et al. } \\
2020)\end{array}$ \\
\hline Micro-emulsion & Easy process & $\begin{array}{c}\text { Poor stability, short storage } \\
\text { time, and high cost of } \\
\text { emulsifiers }\end{array}$ & $\begin{array}{c}\text { (Fazal et al. } \\
2019)\end{array}$ \\
\hline Microwave & $\begin{array}{c}\text { Mild reaction conditions, simple } \\
\text { process, fast reaction, and high } \\
\text { conversion rate }\end{array}$ & $\begin{array}{c}\text { Greatly affected by catalyst } \\
\text { activity }\end{array}$ & $\begin{array}{c}\text { (Gude et al. } \\
2013)\end{array}$ \\
\hline Pyrolysis & $\begin{array}{c}\text { Strong adaptability to raw } \\
\text { materials, simple operation, and } \\
\text { lack of by-product glycerin }\end{array}$ & $\begin{array}{c}\text { Large energy consumption } \\
\text { and immaturity of the } \\
\text { technology }\end{array}$ & $\begin{array}{c}\text { (Koh et al. } \\
2011)\end{array}$ \\
\hline Reactive distillation & $\begin{array}{c}\text { Reduced methanol consumption, } \\
\text { enhanced heat and mass transfer } \\
\text { efficiency, and fast reaction speed }\end{array}$ & $\begin{array}{c}\text { High energy consumption } \\
\text { and strong influence of } \\
\text { catalyst efficiency }\end{array}$ & $\begin{array}{c}\text { (Joda and } \\
\text { Ahmadi et al. } \\
2019)\end{array}$ \\
\hline Super fluid method & $\begin{array}{c}\text { No added catalyst required, fast } \\
\text { reaction rate, and high conversion } \\
\text { efficiency }\end{array}$ & $\begin{array}{c}\text { High price of production } \\
\text { equipment and high energy } \\
\text { consumption }\end{array}$ & $\begin{array}{c}\text { (Chua et al. } \\
2020)\end{array}$ \\
\hline Transesterification & $\begin{array}{c}\text { Ability to produce high quality } \\
\text { biodiesel and suitability for large } \\
\text { scale industrial production }\end{array}$ & $\begin{array}{c}\text { Lower conversion efficiency } \\
\text { and inability to reuse catalyst }\end{array}$ & $\begin{array}{c}\text { (Quah et al. } \\
\text { 2019; } \\
\text { Yesilyurt } \text { et } \\
\text { al. 2019) }\end{array}$ \\
\hline
\end{tabular}


Biodiesel mainly refers to long chain fatty acid alkyl esters, which are formed by transesterification and esterification of alkyl alcohol with lipid biomass raw materials, such as animal oils, vegetable oils, and marine microalgae. The common biodiesel production technologies and their advantages and disadvantages are shown in Table 4 . The production of biodiesel through the catalytic distillation method is a green process that could reduce costs and improve economy. Because of the high cost of traditional precious metal catalysts, low-cost new catalysts that could be recycled and high-activity and highselectivity enzymatic catalysis had been extensively studied (Singh et al. 2019a). The reaction conditions of bio-enzyme-catalyzed synthesis of biodiesel are relatively mild, and the reaction process is more environmentally friendly, but the activity and stability of lipase need to be further improved (Wong et al. 2019). Dilution was a method of reducing the amount of solute in a solution by increasing the amount of solvent. Bioethanol and biodiesel could be used as solvents for diluting oil, but the result of this process was that the density and viscosity of the oil were reduced (Mahlia et al. 2020). Fazal et al. (2019) found that the use of micro-emulsification technology could increase the viscosity of biodiesel. As the temperature increased, the viscosity of the micro-emulsified oil gradually decreased. The processing of microemulsions was easier. But, less volatility, less stability, and high viscosity were still some issues with micro-emulsification. Gude et al. (2013) used microwave technology to produce biodiesel and found that it had the following advantages: low energy consumption, greatly reduced reaction time and solvent requirements, improved selectivity, improved conversion rate, and less by-product formation. However, this method had higher requirements for catalyst, solvent and temperature control. Pyrolysis is a method of preparing biodiesel at high temperature in isolation of air or in an inert atmosphere.

Koh and Ghazi (2011) used Jatropha curcas seed as a raw material to successfully produce biodiesel through pyrolysis and passed the ASTM 7554-10 test, but the production cost was relatively high. Joda et al. (2019) found that biodiesel that was produced by reactive distillation technology had higher reaction conversion efficiency and yield. Compared with the traditional method, its production cost decreased by $15.54 \%$, and the power consumption increased by $2.28 \%$. The supercritical catalytic method for preparing biodiesel has a short reaction time and simple pre-reaction and post-reaction treatments, but extreme process conditions and high equipment costs restrict its further development (Chua et al. 2020).

Among these conversion technologies, transesterification is the most economical and common method for preparing biodiesel, and the biodiesel produced has properties comparable to diesel. The key to the preparation of biodiesel by transesterification is the catalyst. According to the different catalytic methods, transesterification can be divided into homogeneous acid-base catalysis, heterogeneous acid-base catalysis, biological enzyme catalysis, and supercritical catalysis (Quah et al. 2019). Heterogeneous alkali catalysts have the advantages of easy recovery, low corrosion, and environmental friendliness, but the active center of the catalyst is easily lost, the stability is poor, and the preparation steps are complicated. Heterogeneous acid catalysts have high stability and low corrosivity, and they are easily recovered, regenerated, and separated from products. However, the catalytic activity is not high, and the reaction needs to be performed under high pressure and high temperature over a long duration (Yesilyurt et al. 2019). 
Table 5. Application of Nano-catalyst in Transesterification

\begin{tabular}{|c|c|c|c|c|c|c|c|}
\hline Feedstock & Alcohol & $\begin{array}{c}\text { Molar } \\
\text { Ratio } \\
\text { (Alcohol } \\
\text { : Oil) }\end{array}$ & Catalyst & $\begin{array}{l}\text { Catalyst } \\
\text { Size } \\
(\mathrm{nm})\end{array}$ & $\begin{array}{l}\text { Reaction } \\
\text { Conditions }\end{array}$ & $\begin{array}{l}\text { Yield } \\
(\%)\end{array}$ & Reference \\
\hline $\begin{array}{l}\text { Sunflower } \\
\text { oil }\end{array}$ & $\mathrm{CH}_{3} \mathrm{OH}$ & $12: 1$ & $\begin{array}{c}3 \mathrm{wt} \% \\
\mathrm{MgO} / \mathrm{MgAl}_{2} \mathrm{O}_{4}\end{array}$ & $\begin{array}{c}2.4 \text { to } \\
21.3\end{array}$ & $\begin{array}{l}110^{\circ} \mathrm{C} \\
180 \mathrm{~min}\end{array}$ & 95.00 & $\begin{array}{c}\text { (Vahid and } \\
\text { Haghighi } \\
\text { 2017) }\end{array}$ \\
\hline $\begin{array}{c}\text { Sunflower } \\
\text { oil }\end{array}$ & $\mathrm{CH}_{3} \mathrm{OH}$ & $18: 1$ & $\begin{array}{c}3 \mathrm{wt} \% \mathrm{MgO}- \\
\mathrm{La}_{2} \mathrm{O}_{3}\end{array}$ & $\begin{array}{l}15.0- \\
17.8\end{array}$ & $\begin{array}{c}65^{\circ} \mathrm{C}, \\
300 \mathrm{~min}\end{array}$ & 97.70 & $\begin{array}{c}\text { (Feyzi et al. } \\
2017)\end{array}$ \\
\hline $\begin{array}{c}\text { Edible } \\
\text { oil }\end{array}$ & $\mathrm{CH}_{3} \mathrm{OH}$ & $15: 1$ & $\begin{array}{c}4 \mathrm{wt} \% \mathrm{ZnO} / \\
\mathrm{BiFeO}_{3}\end{array}$ & 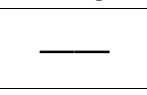 & $\begin{array}{c}65^{\circ} \mathrm{C}, \\
300 \mathrm{~min}\end{array}$ & 95.40 & $\begin{array}{c}\text { (Salimi and } \\
\text { Hosseini 2019) }\end{array}$ \\
\hline Castor oil & $\mathrm{CH}_{3} \mathrm{OH}$ & $8: 1$ & 11 wt\% Ni-ZnO & 31.5 & $\begin{array}{l}55^{\circ} \mathrm{C} \\
60 \mathrm{~min}\end{array}$ & 95.20 & $\begin{array}{c}\text { (Baskar et al. } \\
2018)\end{array}$ \\
\hline $\begin{array}{l}\text { Cotton } \\
\text { seed oil }\end{array}$ & $\mathrm{CH}_{3} \mathrm{OH}$ & $24: 1$ & $\begin{array}{c}12 \text { wt\% 5- } \\
\mathrm{Na} / \mathrm{ZnO}\end{array}$ & 16 & $\begin{array}{c}65^{\circ} \mathrm{C}, \\
240 \mathrm{~min}\end{array}$ & 98.00 & $\begin{array}{l}\text { (Malhotra and } \\
\text { Ali 2019) }\end{array}$ \\
\hline $\begin{array}{c}\text { Refined } \\
\text { vegetable } \\
\text { oil }\end{array}$ & $\mathrm{CH}_{3} \mathrm{OH}$ & $12: 1$ & $\begin{array}{c}\mathrm{Cs}-\mathrm{Ca} / \mathrm{TiO}_{2-} \\
\mathrm{SiO}_{2}\end{array}$ & $\begin{array}{c}40 \text { to } \\
50\end{array}$ & $\begin{array}{c}60^{\circ} \mathrm{C}, 500 \\
\mathrm{rpm}, 120 \\
\min \end{array}$ & 98.00 & $\begin{array}{c}\text { (Feyzi and } \\
\text { Shahbazi } \\
2015)\end{array}$ \\
\hline $\begin{array}{l}\text { Recycled } \\
\text { cooking oil }\end{array}$ & $\mathrm{CH}_{3} \mathrm{OH}$ & $7: 1$ & $\begin{array}{c}3 \mathrm{wt} \% \mathrm{CaO}- \\
\mathrm{MgO}\end{array}$ & $\begin{array}{c}61 \text { to } \\
69\end{array}$ & $\begin{array}{c}65^{\circ} \mathrm{C}, 360 \\
\min \end{array}$ & 98.95 & $\begin{array}{l}\text { (Tahvildari et } \\
\text { al. 2015) }\end{array}$ \\
\hline $\begin{array}{c}\text { Waste } \\
\text { cooking oil }\end{array}$ & $\mathrm{CH}_{3} \mathrm{OH}$ & $8: 1$ & $\begin{array}{c}12 \text { wt\% CZO } \\
\text { nanocomposite }\end{array}$ & 80 & $\begin{array}{c}55^{\circ} \mathrm{C}, 50 \\
\min \end{array}$ & 97.71 & $\begin{array}{l}\text { (Gurunathan } \\
\text { and Ravi } \\
\text { 2015) }\end{array}$ \\
\hline Palm oil & $\mathrm{CH}_{3} \mathrm{OH}$ & $6: 1$ & $\mathrm{TiO}_{2}-\mathrm{ZnO}$ & $\begin{array}{l}85 \text { to } \\
87\end{array}$ & $\begin{array}{c}60^{\circ} \mathrm{C}, 300 \\
\min \end{array}$ & 92.20 & $\begin{array}{l}\text { (Madhuvilakku } \\
\text { and Piraman } \\
\text { 2013) }\end{array}$ \\
\hline
\end{tabular}

In the production of biodiesel, nano-catalyst technology has been widely studied as a new method with high catalytic efficiency. Nano-catalyst technology has high opposition to saponification, high specific surface area, high stability, high activity, and good reusability (Cao et al. 2019; Singh et al. 2019b). As shown in Table 5, various nanocatalysts have been used in transesterification reactions and have achieved extremely high conversion efficiency. Feyzi and Shahbazi (2015) mixed refined vegetable oil and Cs$\mathrm{Ca} / \mathrm{TiO}_{2}-\mathrm{SiO}_{2}$ nano-catalyst to produce biodiesel with a yield of $98 \%$ through the transesterification reaction. The research found that the factors that affect the catalytic activity were the specific surface area, pore size, pore volume, and surface-active site concentration of the catalyst. At the same time, the viscosity, density, and refractive index of biodiesel decreased as the yield increased.

\section{DEVELOPMENT STATUS AND TECHNICAL ANALYSIS OF BIOMASS JET FUEL}

\section{Development Status of Biomass Jet Fuel}

Jet fuel has stricter standards, which require that it be mainly composed of a certain structure and proportion of carbon-based liquid alkanes. The composition of conventional jet fuel is $20 \%$ straight-chain alkanes, $40 \%$ branched alkanes, $20 \%$ cycloalkanes, and $20 \%$ aromatic hydrocarbon. Good low temperature performance, high stability, good lubricity, non-corrosiveness, and low static electricity are required (Mawhood et al. 2016). 


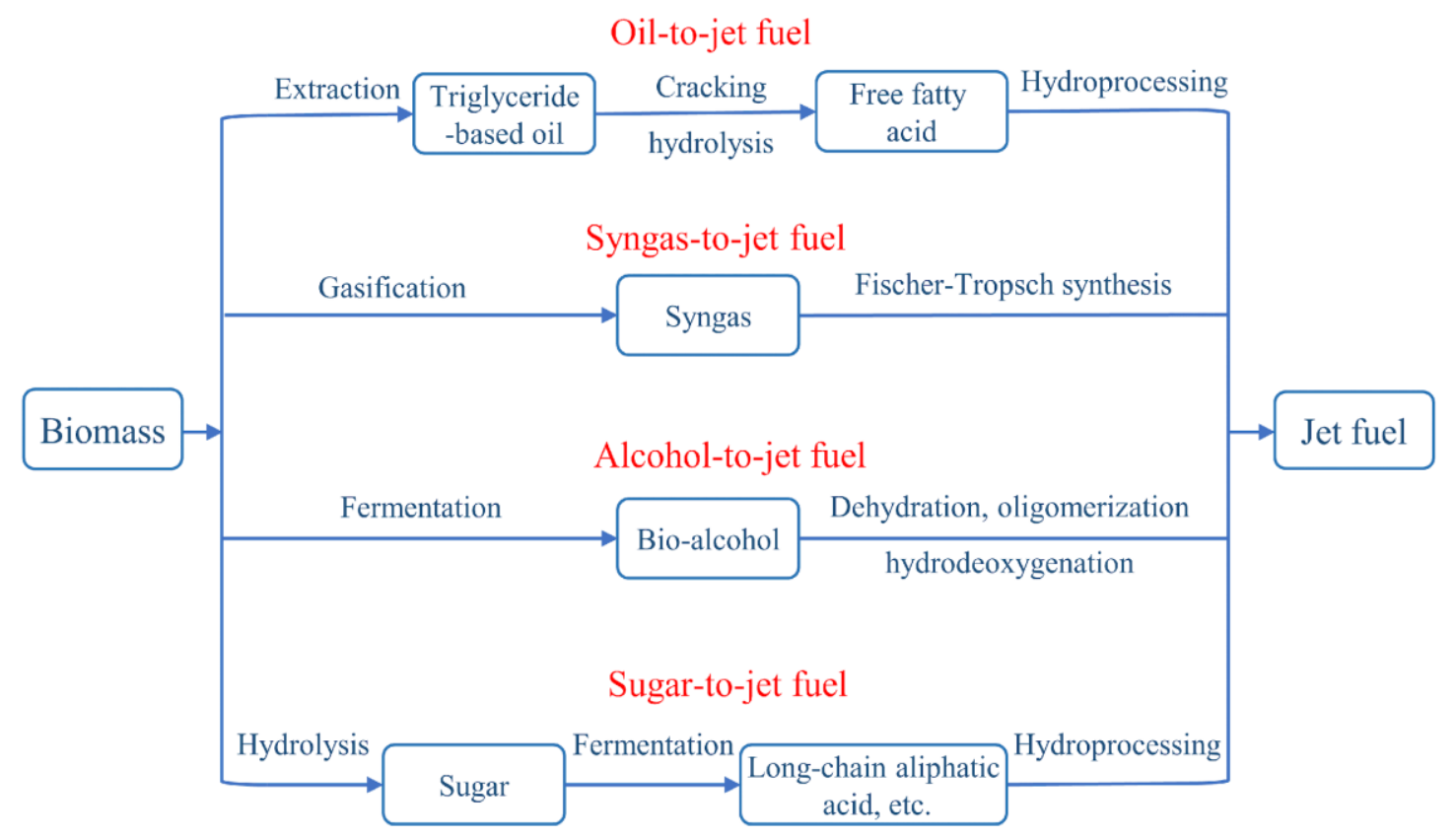

Fig. 1. The main ways to produce jet fuel from biomass

Table 6. The Main Ways to Produce Bio-jet Fuel

\begin{tabular}{|c|c|c|}
\hline $\begin{array}{c}\text { Conversion } \\
\text { Pathway }\end{array}$ & $\begin{array}{l}\text { Conversion } \\
\text { Methods }\end{array}$ & Features \\
\hline $\begin{array}{l}\text { Oil-to-jet } \\
\text { fuel }\end{array}$ & Hydroprocessing & $\begin{array}{l}\text { 1. The preparation process requires strict control of reaction } \\
\text { conditions. 2. Industrial applications have been achieved, but } \\
\text { raw material sources are limited and prices are higher, which } \\
\text { has resulted in high preparation costs (Jamil et al. 2017). }\end{array}$ \\
\hline $\begin{array}{l}\text { Syngas-to- } \\
\text { jet fuel }\end{array}$ & $\begin{array}{l}\text { Gasification, } \\
\text { Fischer-Tropsch, } \\
\quad \text { and } \\
\text { hydroprocessing }\end{array}$ & $\begin{array}{l}\text { 1. The Fischer-Tropsch method has a sufficient supply of } \\
\text { biomass raw materials and mature technology, and the by- } \\
\text { products in the production process are close to petrochemical } \\
\text { products. The products have a lower sulfur content, aromatic } \\
\text { content and carbon dioxide emission. } 2 \text {. Problems include the } \\
\text { long follow-up processing route of synthesis gas, poor product } \\
\text { selectivity, complicated processing procedure, harsh operating } \\
\text { conditions, high investment cost, and choking danger (Wang et } \\
\text { al. 2018; Klayborworn and Pakdee 2019) }\end{array}$ \\
\hline $\begin{array}{l}\text { Alcohol-to- } \\
\text { jet fuel }\end{array}$ & $\begin{array}{l}\text { Dehydration, } \\
\text { oligomerization, } \\
\text { and } \\
\text { hydrogenation }\end{array}$ & $\begin{array}{l}\text { 1. This method is highly dependent on raw materials and } \\
\text { obtaining higher yields of low-carbon alcohols from non-edible } \\
\text { lignocellulose is difficult. } 2 \text {. There are many challenges in the } \\
\text { highly selective dehydrogenation and polymerization of alcohols } \\
\text { during the preparation process (He et al. 2018; Nie et al. 2018) }\end{array}$ \\
\hline $\begin{array}{l}\text { Sugar-to-jet } \\
\text { fuel }\end{array}$ & $\begin{array}{c}\text { Hydrolysis, } \\
\text { fermentation, and } \\
\text { hydroprocessing }\end{array}$ & $\begin{array}{l}\text { 1. This method has the advantages of a mild process and simple } \\
\text { product after-treatment, but the efficiency is low, the yield of the } \\
\text { obtained product is low, and it is difficult to use it industrially. } \\
2 \text {. The direct conversion of biomass into aviation-grade alkane } \\
\text { through fermentation has been a hotspot in biomass } \\
\text { bioconversion in recent years. By cultivating engineered } \\
\text { bacteria and regulating metabolic pathways, this method is } \\
\text { expected to make breakthrough progress (Wei et al. 2019). }\end{array}$ \\
\hline
\end{tabular}


At present, jet fuel is mainly obtained from petrochemical raw materials through cracking, distillation, and isomerization reforming. The use of biomass to produce directly usable jet fuel is a challenging goal. Figure 1 is an adaptation of Wang et al. 2019 (Fig 1). Figure 1 and Table 6 show that researchers have developed several methods for preparing jet fuel from biomass, but most of them can only prepare a certain component of jet fuel (Du and Yan 2016). Jamil et al. (2017) used Phoenix dactylifera kernel oil as the raw material for hydrodeoxygenation. It was found that large fraction of paraffinic hydrocarbons accounted for $91.1 \%$ of the oil. Using $\mathrm{Pd} / \mathrm{C}$ catalyst to produce jet fuel fraction, the product had the density of $0.88 \mathrm{~kg} / \mathrm{m}^{3}$, the viscosity of $3.49 \mathrm{~mm}^{2} / \mathrm{s}$, and the calorific value of $44.11 \mathrm{MJ} / \mathrm{kg}$.

Table 7 is an adaptation of Wang et al. 2019 (Table 1). As shown in Table 7 some bio-jet fuels have been successfully developed on a commercial scale and met the requirements of the American Society for Testing and Materials (ASTM) D7566-17 (2017) standard. These biomass jet fuels can be mixed with petroleum-derived jet fuels with a mixing ratio of up to 50\%. Their production costs are mainly affected by raw material prices, catalyst prices, energy consumption, the efficiency of the conversion process, and related value-added products (Wang et al. 2019). Current commercial airlines reduced carbon emissions by blending bio-jet fuel derived from vegetable oil with fossil jet fuel. Klein et al. (2018) studied the production technology of bio-jet fuel produced by Brazil's sugarcane biorefinery and found that the carbon emissions of bio-jet fuel produced were reduced by $70 \%$ compared to fossil jet fuel. Among them, hydroprocessed esters and fatty acids technology had the highest production capacity. The Fischer-Tropsch synthesis method had the best economic benefits, but the yield was relatively low.

Table 7. Commercial Application to Produce Bio-jet Fuel

\begin{tabular}{|c|c|c|c|c|c|}
\hline $\begin{array}{l}\text { Conversion } \\
\text { Pathway }\end{array}$ & Feedstocks & $\begin{array}{c}\text { Certification } \\
\text { Level }^{*}\end{array}$ & Yield** & $\begin{array}{c}\text { Price } \\
\text { (\$US/gal) }\end{array}$ & References \\
\hline $\begin{array}{l}\text { Oil-to-jet } \\
\text { fuel }\end{array}$ & $\begin{array}{l}\text { Plant } \\
\text { oils, al } \\
\text { pyro }\end{array}$ & $\begin{array}{l}\text { D7566-17 } \\
\text { annex A2* }\end{array}$ & & 2.6 to 34.7 & $\begin{array}{r}\text { (Gutiérre } \\
\text { al. 2017 } \\
2018 ; \mathrm{M} \\
\text { Tyn }\end{array}$ \\
\hline $\begin{array}{l}\text { Syngas-to- } \\
\text { jet fuel }\end{array}$ & & $\begin{array}{l}\text { D7566-17 } \\
\text { annex A1* }\end{array}$ & $9 \mathrm{t}$ & 4.8 to 16.2 & $\begin{array}{r}\text { (Oke } \\
2017 ; \\
2017 \\
\text { Kalts }\end{array}$ \\
\hline $\begin{array}{l}\text { Alcohol-to- } \\
\text { jet fuel }\end{array}$ & Carl & $\begin{array}{l}\text { D7566 } \\
\text { annex }\end{array}$ & 11 & 4.1 to 14.4 & $\begin{array}{r}(\mathrm{Y} \\
\text { Jang } \\
\mathrm{M} \\
\end{array}$ \\
\hline $\begin{array}{l}\text { Sugar- } \\
\text { fue }\end{array}$ & $\begin{array}{l}\text { ars in } \\
\text { ellulose }\end{array}$ & $\begin{array}{l}\text { D7566 } \\
\text { annex }\end{array}$ & 24 & 4.3 to 25.4 & $\begin{array}{r}\text { et al. } 20 \\
\text { al. }\end{array}$ \\
\hline \multicolumn{6}{|c|}{$\begin{array}{l}\text { * ASTM D7566-17 (2017): "Standard specification for aviation turbine fuel containing synthesized } \\
\text { hydrocarbons" was formulated by American Society for Testing and Materials; } \\
\text { Annex A1: Fischer-Tropsch hydroprocessed synthesized paraffinic kerosene; } \\
\text { Annex A2: Synthesized paraffinic kerosine from hydroprocessed esters and fatty acids; } \\
\text { Annex A3: Synthesized iso-paraffins from hydroprocessed fermented sugars; } \\
\text { Annex A5: Alcohol-to-jet synthetic paraffinic kerosene (ATJ-SPK); } \\
\text { ** Yield: Gallon of gasoline equivalent/biomass dry ton }\end{array}$} \\
\hline
\end{tabular}

Han et al. (2017) used sugar-to-jet to prepare bio-jet fuel from corn stover via both biological and catalytic conversion. Compared with petroleum jet fuel, the product could 
reduce greenhouse gas emissions by $59 \%$. The degree of environmental protection and emission reduction were largely depended on the hydrogen source. Alcohol-to-jet produced bio-jet fuel from sugary, starchy, and lignocellulosic biomass via fermentation of sugars to ethanol or other alcohols. Among them, using sugarcane as a raw material had lower costs and fewer risks. Technical uncertainty was the most important factor that affected the economics of the production route. Changes in by-product revenue would greatly affect profitability (Yao et al. 2017).

\section{Technical Analysis of Biomass Jet Fuel}

Figure 2 shows that the production of biomass jet fuel can be accomplished by onestep, two-step, and three-step methods. Wu et al. (2017) used vegetable oils as raw materials to convert into jet fuel through a three-step process. The zeolite catalyst was first used to catalytic crack the vegetable oil into light aromatics, then the ionic liquid was used to aromatically alkylate the light aromatics, and finally the aromatics were hydrogenated. In terms of heat of combustion, $\mathrm{H} / \mathrm{C}$ molar ratio, and average molecular composition, the production of cycloparaffinic and aromatic biofuels could meet the requirements of bio-jet fuels. The three-step process of bio-jet fuel production can also be simplified into a twostep process. Xu et al. (2018) used algae as a raw material to produce biodiesel through a two-step process (hydrothermal liquefaction followed by catalytic upgrading). The final product had similar characteristics to jet fuel. The one-step process is generally simpler than the three-step process, but it has a lower yield. Yield can be improved by further improving the production materials and production processes in a one-step process (Perkins et al. 2019; Yang et al. 2018).

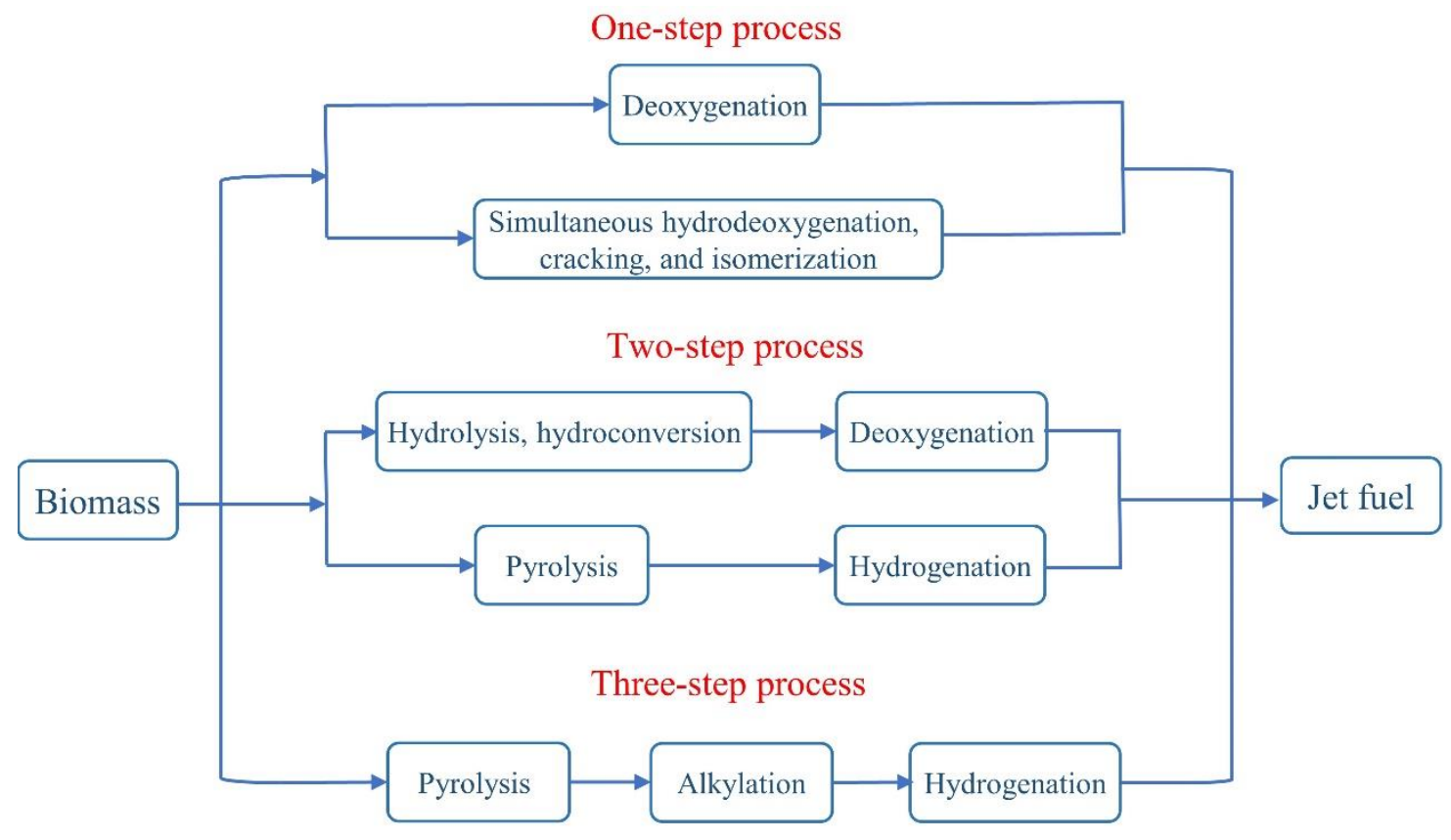

Fig. 2. Summary of current biomass jet fuel preparation technology 
Table 8. Summary of Current Biomass Jet Fuel Preparation Technology

\begin{tabular}{|c|c|c|c|c|}
\hline Feedstocks & Production Steps & $\begin{array}{c}\text { Yield } \\
(\%)\end{array}$ & Major Findings & Reference \\
\hline \multicolumn{5}{|c|}{ Three-step Process } \\
\hline $\begin{array}{l}\text { Commercial } \\
\text { vegetable oil }\end{array}$ & $\begin{array}{l}\text { 1. Pyrolysis; } \\
\text { 2. Alkylation; } \\
\text { 3. Hydrogenation }\end{array}$ & 84.3 & $\begin{array}{l}\text { 1. } \mathrm{C}_{6}-\mathrm{C}_{9} \text { aromatic hydrocarbons can } \\
\text { be obtained by catalytic pyrolysis } \\
\text { from plant oil with a catalyst such as } \\
\text { HZSM-5. } \\
2 . \text { When the carbon number is } \\
\text { between } 8 \text { and } 15 \text {, the carbon } \\
\text { number distribution of the aromatic } \\
\text { hydrocarbons can be adjusted by } \\
\text { changing the reaction temperature } \\
\text { and time in the catalytic cracking } \\
\text { reaction. }\end{array}$ & $\begin{array}{c}\text { (Wu et al. } \\
\text { 2017) }\end{array}$ \\
\hline Straw stalk & $\begin{array}{l}\text { 1. Pyrolysis; } \\
\text { 2. Alkylation; } \\
\text { 3. Hydrogenation }\end{array}$ & 88.4 & $\begin{array}{l}\text { 1. Synthesis of aromatics with } 8 \text { to } \\
15 \text { carbon atoms can be achieved } \\
\text { via alkylation reaction. } \\
\text { 2. Synthesis of cycloalkanes with } 8 \\
\text { to } 15 \text { carbon atoms can be } \\
\text { achieved via hydrogenation reaction } \\
\text { of aromatic hydrocarbons. }\end{array}$ & $\begin{array}{c}\text { (Wang et al. } \\
\text { 2015) }\end{array}$ \\
\hline Saw dust & $\begin{array}{l}\text { 1. Pyrolysis; } \\
\text { 2. Alkylation; } \\
\text { 3. Hydrogenation }\end{array}$ & 80.4 & $\begin{array}{l}\text { 1. Hydrocarbons produced from } \\
\text { sawdust can be used for aviation } \\
\text { and diesel fuels after subjection to } \\
\text { suitable conversion methods. } \\
\text { 2. Hydrocarbons with } 8 \text { to } 15 \\
\text { carbon atoms can be prepared via } \\
\text { alkylation of ionic liquids. }\end{array}$ & $\begin{array}{c}\text { (Zhang et al. } \\
\text { 2015) }\end{array}$ \\
\hline \multicolumn{5}{|c|}{ Two-step Process } \\
\hline $\begin{array}{l}\text { Eucalyptus } \\
\text { sawdust and } \\
\text { discarded } \\
\text { soybean } \\
\text { frying oil }\end{array}$ & $\begin{array}{l}\text { 1. Pyrolysis; } \\
\text { 2. Hydrogenation }\end{array}$ & 60.0 & $\begin{array}{l}\text { 1. Adding discarded soybean frying } \\
\text { oil to eucalyptus sawdust could } \\
\text { increase the yield of oil produced by } \\
\text { pyrolysis of biomass lignin } 40 \% \text { to } \\
50 \% \text {. } \\
\text { 2. The hydrogenation reaction can } \\
\text { greatly improve the stability and } \\
\text { quality of biomass liquid fuels. }\end{array}$ & $\begin{array}{l}\text { (Shah et al. } \\
\text { 2019) }\end{array}$ \\
\hline Algae lipid & $\begin{array}{l}\text { 1. Hydroconversion; } \\
\text { 2. Gas-liquid; } \\
\text { separation }\end{array}$ & 38.0 & $\begin{array}{l}\text { 1. Neutral lipids extracted from wet } \\
\text { algae biomass can be directly } \\
\text { converted into aviation fuel range } \\
\text { paraffin through a one-step catalytic } \\
\text { hydrocracking reaction of composite } \\
\text { catalysts, such as Pt / Meso-ZSM- } 5 \text {. } \\
\text { 2. Compared to the mixed solvent } \\
\text { extraction method, the metal } \\
\text { content of the neutral lipid-rich } \\
\text { fractions prepared from wet algae is } \\
\text { lower by solvent step-by-step } \\
\text { extraction. }\end{array}$ & $\begin{array}{l}\text { (Ju et al. } \\
2018)\end{array}$ \\
\hline Microalgae & $\begin{array}{l}\text { 1. Hydrothermal } \\
\text { liquefaction; } \\
\text { 2. Hydro upgrading }\end{array}$ & 54.4 & $\begin{array}{l}\text { 1. Microalgae that contains a large } \\
\text { amount of lipids has a higher yield } \\
\text { than macroalgae when producing } \\
\text { biomass oil. } \\
\text { 2. Crude bio-oils made from } \\
\text { Schizochytrium limacinum have a }\end{array}$ & $\begin{array}{c}\text { (Xu et al. } \\
\text { 2018) }\end{array}$ \\
\hline
\end{tabular}




\begin{tabular}{|c|c|c|c|c|}
\hline & & & $\begin{array}{c}\text { high energy density after } \\
\text { hydrogenation treatment, and their } \\
\mathrm{N}, \mathrm{O} \text {, and } \mathrm{S} \text { contents and viscosity } \\
\text { were noticeably reduced and have } \\
\text { similar characteristics to aviation } \\
\text { fuels. }\end{array}$ & \\
\hline Palm olein & $\begin{array}{l}\text { 1. Hydrolysis; } \\
\text { 2. Simultaneous } \\
\text { deoxygenation, } \\
\text { cracking, and } \\
\text { isomerization }\end{array}$ & 61.0 & $\begin{array}{c}\text { 1. Using palm olein as the raw } \\
\text { material and } \mathrm{H} \text {-beta zeolite catalyst } \\
\text { without noble metal as the catalyst } \\
\text { for deoxygenation, cracking, and } \\
\text { isomerization under low hydrogen } \\
\text { pressure ( } 10 \text { bar), biomass } \\
\text { hydrocarbons with a freezing } \\
\text { temperature of }-30^{\circ} \mathrm{C} \text { could be } \\
\text { prepared }\end{array}$ & $\begin{array}{l}\text { (Sousa et al. } \\
\text { 2018) }\end{array}$ \\
\hline Algal oil & $\begin{array}{l}\text { 1. Hydrogenation; } \\
\text { 2. Hydrogenolysis }\end{array}$ & 70.0 & $\begin{array}{l}\text { 1. The use of load-type Ru catalysts } \\
\text { in hydrolysis reactions increases } \\
\text { the yield of } C_{5}-C_{12} \text { alkanes. }\end{array}$ & $\begin{array}{c}\text { (Nakaji et al. } \\
\text { 2017) }\end{array}$ \\
\hline \multicolumn{5}{|c|}{ One-step Process } \\
\hline $\begin{array}{l}\text { Waste } \\
\text { cooking oil }\end{array}$ & $\begin{array}{l}\text { 1. Simultaneous } \\
\text { hydrodeoxygenation, } \\
\text { cracking, and } \\
\text { isomerization }\end{array}$ & 39.7 & $\begin{array}{l}\text { 1. SBUY-MCM-41 zeolite has a } \\
\text { special layered structure, high } \\
\text { acidity, and hydrothermal stability. } \\
\text { 2. Loading NiMo catalyst on SBUY- } \\
\text { MCM-41 could noticeably enhance } \\
\text { the selective cracking of } \\
\text { hydrocarbons in the jet fuel range } \\
\text { by waste cooking oil. }\end{array}$ & $\begin{array}{c}\text { (Zhang et al. } \\
\text { 2019) }\end{array}$ \\
\hline $\begin{array}{l}\text { Cotton seed } \\
\text { oil dregs }\end{array}$ & 1. Micro pyrolysis & 32.0 & $\begin{array}{l}\text { 1. The presence of water in the } \\
\text { biomass feedstock is conducive to } \\
\text { cracking reactions, thereby } \\
\text { increasing the yield of biomass oil. }\end{array}$ & $\begin{array}{l}\text { (Dos Santos } \\
\text { Souza et al. } \\
\text { 2018) }\end{array}$ \\
\hline $\begin{array}{l}\text { Bamboo } \\
\text { waste and } \\
\text { Spirulina } \\
\text { platensis }\end{array}$ & $\begin{array}{l}\text { 1. Deoxygenation } \\
\text { co-pyrolysis }\end{array}$ & 36.8 & $\begin{array}{l}\text { 1. The co-pyrolysis of bamboo } \\
\text { waste and microalgae with biochar } \\
\text { catalyst could effectively remove } \\
\text { oxygen and maintain oil fraction } \\
\text { yield. }\end{array}$ & $\begin{array}{l}\text { (Chen et al. } \\
\text { 2018) }\end{array}$ \\
\hline $\begin{array}{l}\text { Camelina, } \\
\text { carinata, and } \\
\text { used } \\
\text { cooking oil }\end{array}$ & $\begin{array}{c}1 . \\
\text { Hydrodeoxygenation }\end{array}$ & 54.0 & $\begin{array}{l}\text { 1. Relatively unsaturated } \\
\text { feedstocks consumed more } \\
\text { hydrogen and energy than more } \\
\text { saturated feed stocks when } \\
\text { cracking to produce alkanes. }\end{array}$ & $\begin{array}{l}\text { (Chu et al. } \\
\text { 2017) }\end{array}$ \\
\hline
\end{tabular}

The current research and main findings on biomass jet fuel are shown in Table 8 . Table 8 shows that the yield of biomass jet fuel from the three-step process is generally high, as it has a minimum yield of $72.5 \%$. The three-step production process can be further simplified to the two-step process. Nakaji et al. (2017) used algal oil as a feedstock to perform two steps of hydrogenation and hydrogenolysis, which could produce jet fuel with a yield of up to $64 \%$. One-step production of biomass jet fuel has become the latest research trend. However, there are still many challenges and limitations in the selection of raw materials, catalysts, and reaction parameters. It is necessary to explore more potential raw materials and develop new catalysts suitable for the one-step process (Why et al. 2019). The yield of biomass jet fuel from the one-step process is low at generally less than $40 \%$. Chu et al. (2017) used nitrogen instead of hydrogen to achieve the deoxidation of bio-oil, thereby increasing the yield of biomass jet fuel by the one-step process to $54 \%$. This 
indicates that the use of nitrogen will improve the dependence of the deoxygenation process on hydrogen.

\section{CONCLUDING REMARKS}

Biomass liquid fuel can be regarded as the most important form of renewable, green, clean, and recyclable biomass energy. Its development and research will be one of the major hot topics in the world for a long time to come.

Biomass liquid fuel conversion technology can be strengthened by reducing the energy consumption in the process of bio-converting ethanol, developing suitable and economically feasible hydrolysis process steps, and improving the conversion and yield of cellulose and hemicellulose. Genetic engineering should be used to genetically modify cellulase and fermentation microorganisms to improve fermentation efficiency. In addition, the breeding of high-efficiency fermentation strains suitable for complex fermentation environments should also be pursued to increase ethanol production.

The development of cheap catalysts with high activity, high stability, high utilization rate, and environmentally friendly and cost-effective production processes is the key to promoting the large-scale, stable development of biodiesel.

Exploring new reaction paths and simplifying tedious reaction steps using favorable strategies, such as the one-step method, are the future trends of biomass-to-jet fuel. Existing hydrodeoxygenation reactions often rely on precious metal catalysts, and the development of cheap, stable, and efficient catalysts is critical for the industrial application of biomass jet fuels. Research and development of co-production technologies for high-quality biomass fuels and high value-added chemicals can reduce conversion costs and greatly improve resource utilization.

In summary, how to improve the conversion of raw materials and product yields, reduce the side reaction process, and develop clean and efficient new production processes will be hot research topics for the preparation of biomass liquid fuels in the future. In the future development of the energy industry, as a new type of energy strategic industry, further research and development and application of bio-liquid fuels are required to fully elucidate the economic and ecological benefits of bio-liquid fuels.

\section{ACKNOWLEDGEMENTS}

This study was funded by the National Key R\&D Program of China (Grant No. 2018YFD0700200) and the National Natural Science Foundation of China (Grant No. 21978308).

\section{REFERENCES CITED}

ASTM D7566-17(2017). "Standard specification for aviation turbine fuel containing synthesized hydrocarbons," American Society for Testing and Material

Ayodele, B. V., Alsaffar, M. A., and Mustapa, S. I. (2019). “An overview of integration opportunities for sustainable bioethanol production from first-and second-generation 
sugar-based feedstocks," Journal of Cleaner Production 245, Article ID 118857. DOI: 10.1016/j.jclepro.2019.118857

Baskar, G., Selvakumari, I. A. E., and Aiswarya, R. (2018). "Biodiesel production from castor oil using heterogeneous Ni doped ZnO nanocatalyst," Bioresource Technology 250, 793-798. DOI: 10.1016/j.biortech.2017.12.010

Cao, D., Zhang, B., Yang, M., Luo, F., Yang, X., and Zhu, S. (2019). "Use of single atom catalysis for improvement of lignocellulosic conversion," BioResources 14(3), 50185021. DOI: 10.15376/biores.14.3.5018-5021

Carrasco, C., Baudel, H.M., Sendelius, J., Modig, T., Roslander, C., Galbe, M., HahnHägerdal, B., Zacchi, G., and Lidén, G. (2010). "SO2-catalyzed steam pretreatment and fermentation of enzymatically hydrolyzed sugarcane bagasse," Enzyme and Microbial Technology 46(2), 64-73. DOI: 10.1016/j.enzmictec.2009.10.016

Chen, W., Li, K., Xia, M., Yang, H., Chen, Y., Chen, X., Che, Q., and Chen, H. (2018). "Catalytic deoxygenation co-pyrolysis of bamboo wastes and microalgae with biochar catalyst," Energy 157, 472-482. DOI: 10.1016/j.energy.2018.05.149

Chu, P. L., Vanderghem, C., MacLean, H. L., and Saville, B. A. (2017). "Process modeling of hydrodeoxygenation to produce renewable jet fuel and other hydrocarbon fuels," Fuel 196, 298-305. DOI: 10.1016/j.fuel.2017.01.097

Chua, S. Y., Goh, C. M. H., Tan, Y. H., Mubarak, N. M., Kansedo, J., Khalid, M., Walvekar, R., and Abdullah, E. (2020). "Biodiesel synthesis using natural solid catalyst derived from biomass waste - A review," Journal of Industrial and Engineering Chemistry 81, 41-60. DOI: 10.1016/j.jiec.2019.09.022

Dabros, T. M. H., Stummann, M. Z., Høj, M., Jensen, P. A., Grunwaldt, J. D., Gabrielsen, J., Mortensen, P. M., and Jensen, A. D. (2018). "Transportation fuels from biomass fast pyrolysis, catalytic hydrodeoxygenation, and catalytic fast hydropyrolysis," Progress in Energy and Combustion Science 68, 268-309. DOI: 10.1016/j.pecs.2018.05.002

Dave, N., Selvaraj, R., Varadavenkatesan, T., and Vinayagam, R. (2019). “A critical review on production of bioethanol from macroalgal biomass," Algal Research 42, Article ID 101606. DOI: 10.1016/j.algal.2019.101606

Dos Santos Souza, T. G., Santos, B. L. P., Santos, A. M. A., De Souza, A. M. G. P., he Melo, J. C., and Wisniewski, A. (2018). "Thermal and catalytic micropyrolysis for conversion of cottonseed oil dregs to produce biokerosene," Journal of Analytical and Applied Pyrolysis 129, 21-28. DOI: 10.1016/j.jaap.2017.12.010

Du, H., and Yan, C. (2016). "Preparation technologies of liquid fuel from biomass," Contemporary Chemical Industry 45(8), 1997-2000.

Efeovbokhan, V. E., Egwari, L., Alagbe, E. E., Adeyemi, J. T., and Taiwo, O. S. (2019). "Production of bioethanol from hybrid cassava pulp and peel using microbial and acid hydrolysis," BioResources 14(2), 2596-2609. DOI: 10.15376/biores.14.2.2596-2609

El Harchi, M., Kachkach, F. F., and El Mtili, N. (2018). "Optimization of thermal acid hydrolysis for bioethanol production from Ulva rigida with yeast Pachysolen tannophilus," South African Journal of Botany 115, 161-169. DOI: 10.1016/j.sajb.2018.01.021

Fazal, M. A., Rubaiee, S., and Al-Zahrani, A. (2019). "Overview of the interactions between automotive materials and biodiesel obtained from different feedstocks," Fuel Processing Technology 196, Article ID 106178. DOI: 10.1016/j.fuproc.2019.106178 
Feyzi, M., and Shahbazi E. (2015). "Catalytic performance and characterization of Cs$\mathrm{Ca} / \mathrm{SiO}_{2}-\mathrm{TiO}_{2}$ nanocatalysts for biodiesel production," Journal of Molecular Catalysis A: Chemical 4, 5-29. DOI: 10.1016/j.molcata.2015.04.018

Feyzi, M., Hosseini, N., Yaghobi, N., and Ezzati, R. (2017). "Preparation, characterization, kinetic and thermodynamic studies of $\mathrm{MgO}-\mathrm{La}_{2} \mathrm{O}_{3}$ nanocatalysts for biodiesel production from sunflower oil," Chemical Physics Letters 677, 19-29. DOI: 10.1016/j.cplett.2017.03.014

Gude, V., Patil, P., Martinez-Guerra, E., Deng, S., and Nirmalakhandan, N. (2013). "Microwave energy potential for biodiesel production," Sustain. Chem. Process 5, 15. DOI: 10.1186/2043-7129-1-5.

Guerrero, A. B., Ballesteros, I., and Ballesteros, M. (2018). "The potential of agricultural banana waste for bioethanol production," Fuel 213, 176-185. DOI: 10.1016/j.fuel.2017.10.105

Gurunathan, B., and Ravi, A. (2015). "Biodiesel production from waste cooking oil using copper doped zinc oxide nanocomposite as heterogeneous catalyst," Bioresource Technology 188, 124-127. DOI:10.1016/j.biortech.2015.01.012

Gutiérrez-Antonio, C., Gómez-Castro, F., De Lira-Flores, J., and Hernández, S. (2017). "A review on the production processes of renewable jet fuel," Renewable and Sustainable Energy Reviews 79, 709-729. DOI: 10.1016/j.rser.2017.05.108

Han, J., Tao L., and Wang M. (2017). "Well-to-wake analysis of ethanol-to-jet and sugarto-jet pathways," Biotechnology for Biofuels 10(1), 21-36.10. DOI: 1186/s13068-0170698-z

He, M., Wang, M., Tang, G., Fang, Y., and Tan, T. (2018). "From medium chain fatty alcohol to jet fuel: Rational integration of selective dehydration and hydroprocessing," Applied Catalysis A: General 550, 160-167. DOI: 10.1016/j.apcata.2017.11.009

Jamil, F., Al-Muhatseb, A. H., Al-Haj, L., Al-Hinai, M. A., and Baawain, M. (2017). "Phoenix dactylifera kernel oil used as potential source for synthesizing jet fuel and green diesel," Energy Procedia 118, 35-39. DOI: 10.1016/j.egypro.2017.07.006

Jang, M.-O., and Choi, G. (2018). "Techno-economic analysis of butanol production from lignocellulosic biomass by concentrated acid pretreatment and hydrolysis plus continuous fermentation," Biochemical Engineering Journal 134, 30-43. DOI: 10.1016/j.bej.2018.03.002

Jmel, M. A., Anders, N., Yahmed, N. B., Schmitz, C., Marzouki, M. N., Spiess, A., and Smaali, I. (2018). "Variations in physicochemical properties and bioconversion efficiency of Ulva lactuca polysaccharides after different biomass pretreatment techniques," Applied Biochemistry and Biotechnology 184(3), 777-793. DOI: 10.1007/s12010-017-2588-z

Joda, F., and Ahmadi, F. (2019). "Exergoeconomic analysis of conventional and using reactive distillation biodiesel production scenarios thermally integrated with a combined power plant," Renewable Energy 132, 898-910. DOI: 10.1016/j.renene.2018.08.052

Ju, C., Wang, F., Huang, Y., and Fang, Y. (2018). "Selective extraction of neutral lipid from wet algae paste and subsequently hydroconversion into renewable jet fuel," Renewable Energy 118, 521-526. DOI: 10.1016/j.renene.2017.11.028

Kabir, F., Gulfraz, M., Raja, G. K., Inam-ul-Haq, M., Batool, I., Awais, M., Habiba, U., and Gul, H. (2019). "Comparative study on the usability of lignocellulosic and algal 
biomass for production of alcoholic fuels," BioResources 14(4), 8135-8154. DOI: 10.15376/biores. 14.4.8135-8154

Kim, S. W., Kim, Y.-W., Hong, C.-H., Lyo, I.-W., Lim, H.-D., Kim, G.-J., and Shin, H.J. (2018). "Recombinant agarase increases the production of reducing sugars from HCl-treated Gracilaria verrucosa, a red algae," Algal Research 31, 517-524. DOI: 10.1016/j.algal.2017.01.008

Klayborworn, S., and Pakdee, W. (2019). "Effects of porous insertion in a round-jet burner on flame characteristics of turbulent non-premixed syngas combustion," Case Studies in Thermal Engineering 14, Article ID 100451. DOI: 10.1016/j.csite.2019.100451

Klein, B. C., Chagas, M. F., Junqueira, T. L., Rezende, M. C. A. F., De Fátima Cardoso, T., Cavalett, O., and Bonomi, A. (2018). "Techno-economic and environmental assessment of renewable jet fuel production in integrated Brazilian sugarcane biorefineries," Applied Energy 209, 290-305. DOI: 10.1016/j.apenergy.2017.10.079

Koh, M. Y., and Ghazi, T. (2011). "A review of biodiesel production from Jatropha curcas L. oil," Renewable \& Sustainable Energy Reviews 15(5), 2240-2251. DOI: 10.1016/j.rser.2011.02.013

Krishnan, C., Sousa, L. D. C., Jin, M., Chang, L., Dale, B. E., and Balan, V. (2010). "Alkali-based AFEX pretreatment for the conversion of sugarcane bagasse and cane leaf residues to ethanol," Biotechnology and Bioengineering 107, 441-450. DOI: 10.1002/bit.22824

Lau, M. W., and Dale, B. E. (2010). "Effect of primary degradation-reaction products from Ammonia Fiber Expansion (AFEX)-treated corn stover on the growth and fermentation of Escherichia coli KO11. Bioresource Technology 101(20), 78497855. DOI: 10.1016/j.biortech.2010.04.076

Li, Y., Zhao, C., Chen, L., Zhang, X., Zhang, Q., Wang, T., Qiu, S., Tan, J., Li, K., and Wang, C. (2018). "Production of bio-jet fuel from corncob by hydrothermal decomposition and catalytic hydrogenation: Lab analysis of process and technoeconomics of a pilot-scale facility," Applied Energy 227, 128-136. DOI: 10.1016/j.apenergy.2017.07.133

Madhuvilakku, R., and Piraman, S. (2013). "Biodiesel synthesis by $\mathrm{TiO}_{2}-\mathrm{ZnO}$ mixed oxide nanocatalyst catalyzed palm oil transesterification process," Bioresour Technol, 150, 55-59. DOI:10.1016/j.biortech.2013.09.087

Mahlia, T. M. I., Syazmi, Z. A. H. S., Mofijur, M., Abas, A. E. P., Bilad, M. R., Ong, H. C., and Silitonga, A. S. (2020). "Patent landscape review on biodiesel production: Technology updates," Renewable and Sustainable Energy Reviews 118, Article ID 109526. DOI: 10.1016/j.rser.2019.109526

Malhotra, R., and Ali, A. (2019). "5-Na/ZnO doped mesoporous silica as reusable solid catalyst for biodiesel production via transesterification of virgin cottonseed oil," Renewable Energy 133, 606-619. DOI: 10.1016/j.renene.2018.10.055

Malihan, L. B., Mittal, N., Nisola, G. M., Weldemhret, T. G., Kim, H., and Chung, W.-J. (2017). "Macroalgal biomass hydrolysis using dicationic acidic ionic liquids," Journal of Chemical Technology \& Biotechnology 92(6), 1290-1297. DOI: $10.1002 /$ jctb.5123

Mawhood, R., Gazis, E., De Jong, S., Hoefnagels, R., and Slade, R. (2016). "Production pathways for renewable jet fuel: A review of commercialization status and future prospects," Biofuels, Bioproducts and Biorefining 10(4), 462-484. DOI: $10.1002 / \mathrm{bbb} .1644$ 
McGarvey, E., and Tyner, W. E. (2018). "A stochastic techno-economic analysis of the catalytic hydrothermolysis aviation biofuel technology," Biofuels, Bioproducts and Biorefining 12(3), 474-484. DOI: 10.1002/bbb.1863

Michailos, S. (2018). "Process design, economic evaluation and life cycle assessment of jet fuel production from sugar cane residue," Environmental Progress \& Sustainable Energy 37(3), 1227-1235. DOI: 10.1002/ep.12840

Nakaji, Y., Oya, S.-I., Watanabe, H., Watanabe, M. M., Nakagawa, Y., Tamura, M., and Tomishige, K. (2017). "Production of gasoline fuel from alga-derived botryococcene by hydrogenolysis over ceria-supported ruthenium catalyst," ChemCatChem 9(14), 2701-2708. DOI: $10.1002 /$ cctc. 201700200

Neuling, U., and Kaltschmitt, M. (2018). "Techno-economic and environmental analysis of aviation biofuels," Fuel Processing Technology 171, 54-69. DOI: 10.1016/j.fuproc.2017.09.022

Nie, G., Zhang, X., Pan, L., Wang, M., and Zou, J.-J. (2018). "One-pot production of branched decalins as high-density jet fuel from monocyclic alkanes and alcohols," Chemical Engineering Science 180, 64-69. DOI: 10.1016/j.ces.2018.01.024

Okeke, I. J., and Mani, S. (2017). "Techno-economic assessment of biogas to liquid fuels conversion technology via Fischer-Tropsch synthesis," Biofuels, Bioproducts and Biorefining 11(3), 472-487. DOI: 10.1002/bbb.1758

Olcay, H., Malina, R., Upadhye, A. A., Hileman, J. I., Huber, G. W., and Barrett, S. R. H. (2018). "Techno-economic and environmental evaluation of producing chemicals and drop-in aviation biofuels via aqueous phase processing," Energy \& Environmental Science 11(8), 2085-2101. DOI: 10.1039/c7ee03557h

Olofsson, K., Bertilsson, M., and Lidén, G. (2008). "A short review on SSF-an interesting process option for ethanol production from lignocellulosic feedstocks," Biotechnology for Biofuels 1(1), 1-14. DOI: 10.1186/1754-6834-1-7

Perkins, G., Batalha, N., Kumar, A., Bhaskar, T., and Konarova, M. (2019). "Recent advances in liquefaction technologies for production of liquid hydrocarbon fuels from biomass and carbonaceous wastes," Renewable and Sustainable Energy Reviews 115, Article ID 109400. DOI: 10.1016/j.rser.2019.109400

Quah, R. V., Tan, Y. H., Mubarak, N. M., Khalid, M., Abdullah, E. C., and NolascoHipolito, C. (2019). "An overview of biodiesel production using recyclable biomass and non-biomass derived magnetic catalysts," Journal of Environmental Chemical Engineering 7(4), Article ID 103219. DOI: 10.1016/j.jece.2019.103219

Salimi, Z., and Hosseini, S. A. (2019). "Study and optimization of conditions of biodiesel production from edible oils using $\mathrm{ZnO} / \mathrm{BiFeO}_{3}$ nano magnetic catalyst," Fuel 239, 1204-1212. DOI: 10.1016/j.fuel.2018.11.125

Saravanan, K., Duraisamy, S., Ramasamy, G., Kumarasamy, A., and Balakrishnan, S. (2018). "Evaluation of the saccharification and fermentation process of two different seaweeds for an ecofriendly bioethanol production," Biocatalysis and Agricultural Biotechnology 14, 444-449. DOI: 10.1016/j.bcab.2018.03.017

Shah, Z., Veses, R. C., Vaghetti, J. C. P., Amorim, V. D. A., and Da Silva, R. (2019). "Preparation of jet engine range fuel from biomass pyrolysis oil through hydrogenation and its comparison with aviation kerosene," International Journal of Green Energy 16(4), 350-360. DOI: 10.1080/15435075.2019.1566730

Shen, R., Tao, L., and Yang, B. (2019). "Techno-economic analysis of jet-fuel production from biorefinery waste lignin," Biofuels, Bioproducts and Biorefining 13(3), 486-501. DOI: $10.1002 / \mathrm{bbb} .1952$ 
Sikarwar, V. S., Zhao, M., Fennell, P. S., Shah, N., and Anthony, E. J. (2017). "Progress in biofuel production from gasification," Progress in Energy and Combustion Science 61, 189-248. DOI: 10.1016/j.pecs.2017.04.001

Singh, D., Sharma, D., Soni, S. L., Sharma, S., and Kumari, D. (2019a). "Chemical compositions, properties, and standards for different generation biodiesels: A review," Fuel 253, 60-71. DOI: 10.1016/j.fuel.2019.04.174

Singh, D., Sharma, D., Soni, S. L., Sharma, S., Sharma, P. K., and Jhalani, A. (2019b). "A review on feedstocks, production processes, and yield for different generations of biodiesel," Fuel 262, Article ID 116553. DOI: 10.1016/j.fuel.2019.116553

Soliman, R. M., Younis, S. A., El-Gendy, N. S., Mostafa, S., El-Temtamy, S. A., and Hashim, A. I. (2018). "Batch bioethanol production via the biological and chemical saccharification of some Egyptian marine macroalgae," Journal of Applied Microbiology 125(2), 422-440. DOI: 10.1111/jam.13886

Song, Y., Cho, E. J., Park, C. S., Oh, C. H., Park, B.-J., and Bae, H.-J. (2019). “A strategy for sequential fermentation by Saccharomyces cerevisiae and Pichia stipitis in bioethanol production from hardwoods," Renewable Energy 139, 1281-1289. DOI: 10.1016/j.renene.2019.03.032

Sousa, F. P., Silva, L. N., De Rezende, D. B., De Oliveira, L. C. A., and Pasa, V. M. D. (2018). "Simultaneous deoxygenation, cracking and isomerization of palm kernel oil and palm olein over beta zeolite to produce biogasoline, green diesel and biojet-fuel," Fuel 223, 149-156. DOI: 10.1016/j.fuel.2018.03.020

Subsamran, K., Mahakhan, P., Vichitphan, K., Vichitphan, S., and Sawaengkaew, J. (2019). "Potential use of vetiver grass for cellulolytic enzyme production and bioethanol production," Biocatalysis and Agricultural Biotechnology 17, 261-268. DOI: 10.1016/j.bcab.2018.11.023

Sudhakar, M., Merlyn, R., Arunkumar, K., and Perumal, K. (2016). "Characterization, pretreatment and saccharification of spent seaweed biomass for bioethanol production using baker's yeast," Biomass and Bioenergy 90, 148-154. DOI:

10.1016/j.biombioe.2016.03.031

Tahvildari, K., Anaraki, Y. N., Fazaeli, R., Mirpanji, S., and Delrish, E. (2015). "The study of $\mathrm{CaO}$ and $\mathrm{MgO}$ heterogenic nano-catalyst coupling on transesterification reaction efficacy in the production of biodiesel from recycled cooking oil," Journal of Environmental Health Science and Engineering 13(1), 1-9. DOI: 10.1186/s40201015-0226-7

Vahid, B. R., and Haghighi, M. (2017). "Biodiesel production from sunflower oil over $\mathrm{MgO} / \mathrm{MgAl}_{2} \mathrm{O}_{4}$ nanocatalyst: Effect of fuel type on catalyst nanostructure and performance," Energy Conversion and Management 134, 290-300. DOI: 10.1016/j.enconman.2016.12.048

Vintila, T., Ionel, I., Tiegam, R. F. T., Wächter, A. R., Julean, C., and Gabche, A. S. (2019). "Residual biomass from food processing industry in Cameroon as feedstock for second-generation biofuels," BioResources 14(2), 3731-3745. DOI: 10.15376/biores.14.2.3731-3745

Wang, J., Bi, P., Zhang, Y., Xue, H., Jiang, P., Wu, X., Liu, J., Wang, T., and Li, Q. (2015). "Preparation of jet fuel range hydrocarbons by catalytic transformation of biooil derived from fast pyrolysis of straw stalk," Energy 86, 488-499. DOI: 10.1016/j.energy.2015.04.053 
Wang, N., Liu, J., Chang, W. L., and Chia-Fon, F. L. (2018). "A numerical study on effects of pre-chamber syngas reactivity on hot jet ignition," Fuel 234, 1-8. DOI: 10.1016/j.fuel.2018.06.124

Wang, H., Yang, B., Zhang, Q., and Zhu, W. (2019). "Catalytic routes for the conversion of lignocellulosic biomass to aviation fuel range hydrocarbons," Renewable and Sustainable Energy Reviews 120, Article ID 109612. DOI: 10.1016/j.rser.2019.109612

Wei, H., Liu, W., Chen, X., Yang, Q., Li, J., and Chen, H. (2019). "Renewable bio-jet fuel production for aviation: A review," Fuel 254, Article ID 115599. DOI: 10.1016/j.fuel.2019.06.007

Why, E. S. K., Ong, H. C., Lee, H. V., Gan, Y. Y., Chen, W.-H., and Chong, C. T. (2019). "Renewable aviation fuel by advanced hydroprocessing of biomass: Challenges and perspective," Energy Conversion and Management 199, Article ID 112015. DOI: 10.1016/j.enconman.2019.112015

Widyaningrum, T., Prastowo, I., Parahadi, M., and Prasetyo, A. D. (2016). "Production of bioethanol from the hydrolysate of brown seaweed (Sargassum crassifolium) using a naturally $\beta$-glucosidase producing yeast Saccharomyces cerevisiae JCM 3012," Biosciences Biotechnology Research Asia 13(3), 1333-1340. DOI: $10.13005 / \mathrm{bbra} / 2274$

Wong, K. Y., Ng, J.-H., Chong, C. T., Lam, S. S., and Chong, W. T. (2019). "Biodiesel process intensification through catalytic enhancement and emerging reactor designs: A critical review," Renewable and Sustainable Energy Reviews 116, Article ID 109399. DOI: 10.1016/j.rser.2019.109399

Wu, X., Jiang, P., Jin, F., Liu, J., Zhang, Y., Zhu, L., Xia, T., Shao, K., Wang, T., and Li, Q. (2017). "Production of jet fuel range biofuels by catalytic transformation of triglycerides-based oils," Fuel 188, 205-211. DOI: 10.1016/j.fuel.2016.10.030

Xu, Y.-P., Duan, P.-G., Wang, F., and Guan, Q.-Q. (2018). "Liquid fuel generation from algal biomass via a two-step process: Effect of feedstocks," Biotechnology for Biofuels 11(1), Article number 83. DOI: 10.1186/s13068-018-1083-2

Yahmed, N. B., Berrejeb, N., Jmel, M. A., Jazzar, S., Marzouki, M. N., and Smaali, I. (2018). "Efficient biocatalytic conversion of stranded green macroalgal biomass using a specific cellulases-based cocktail," Waste and Biomass Valorization 11, 211-222. DOI: $10.1007 / \mathrm{s} 12649-018-0397-4$

Yang, Z., Qian, K., Zhang, X., Lei, H., Xin, C., Zhang, Y., Qian, M., and Villota, E. (2018). "Process design and economics for the conversion of lignocellulosic biomass into jet fuel range cycloalkanes," Energy 154(1), 289-297. DOI: 10.1016/j.energy.2018.04.126

Yao, G., Staples, M. D., Malina, R., and Tyner, W. E. (2017). "Stochastic technoeconomic analysis of alcohol-to-jet fuel production," Biotechnology for Biofuels 10(1), Article number 18. DOI: 10.1186/s13068-017-0702-7

Ye, G., Zeng, D., Zhang, S., Fan, M., Zhang, H., and Xie, J. (2018). "Ethanol production from mixtures of sugarcane bagasse and Dioscorea composita extracted residue with high solid loading," Bioresource Technology 257, 23-29. DOI:

10.1016/j.biortech.2018.02.008

Yesilyurt, M. K., Cesur, C., Aslan, V., and Yilbasi, Z. (2019). "The production of biodiesel from safflower (Carthamus tinctorius L.) oil as a potential feedstock and its usage in compression ignition engine: A comprehensive review," Renewable and 
Sustainable Energy Reviews 119, Article ID 109574. DOI:

10.1016/j.rser.2019.109574

Zhang, Y., Bi, P., Wang, J., Jiang, P., Wu, X., Xue, H., Liu, J., Zhou, X., and Li, Q. (2015). "Production of jet and diesel biofuels from renewable lignocellulosic biomass," Applied Energy 150, 128-137. DOI: 10.1016/j.apenergy.2015.04.023

Zhang, Z., Wang, Q., and Zhang, X. (2019). "Hydroconversion of waste cooking oil into bio-Jet fuel over NiMo/SBUY-MCM-41," Catalysts 9(5), Article number 466. DOI: $10.3390 /$ catal 9050466

Article submitted: February 21, 2020; Peer review completed: July 4, 2020; Revised version received and accepted: March 31, 2021; Published: April 8, 2021.

DOI: 10.15376/biores.16.2.Zhang 